Pharmaciana

Vol.7, No.1, Mei 2017, Hal. 41-52

ISSN: 2088 4559; e-ISSN: 24770256

DOI: $10.12928 /$ pharmaciana.v7i1.5193

\title{
Gambaran pelaksanaan swamedikasi dan pendapat konsumen apotek mengenai konseling obat tanpa resep di wilayah Bantul
}

\author{
Susan Fitria Candradewi ${ }^{1}$, Susi Ari Kristina ${ }^{2}$ \\ ${ }^{1}$ Fakultas Farmasi, Universitas Ahmad Dahlan \\ Jl.Prof.Dr. Soepomo, S.H.,Yogyakarta \\ ${ }^{2}$ Bagian Farmasetika, Fakultas Farmasi, Universitas Gadjah Mada \\ Jl. Sekip Utara, Yogyakarta, Daerah Istimewa Yogyakarta
}

Submitted: 15-11-2016

Reviewed: 16-03-2017

Accepted: 24-04-2017

\begin{abstract}
ABSTRAK
Penggunaan obat tanpa resep dalam upaya swamedikasi telah dilakukan secara luas oleh masyarakat untuk mengobati berbagai kondisi penyakit ringan. Obat-obat yang sering digunakan dalam swamedikasi pada umumnya termasuk ke dalam golongan obat tanpa resep. Perilaku masyarakat dalam swamedikasi dipengaruhi beberapa hal salah satunya kemudahan mengakses berbagai informasi mengenai obat, dan juga merupakan salah satu pertimbangan konsumen dalam pemilihan obat. Perkembangan konsep "Pelayanan Kefarmasian" berarti Apoteker secara langsung bertanggung jawab pada pasien dalam peningkatkan mutu pelayanan sehingga Apoteker memiliki kewajiban dalam pemberian informasi yang benar terkait penggunaan obat-obat tanpa resep. Penelitian ini bertujuan untuk mengetahui pendapat konsumen apotek mengenai konseling obat tanpa resep dan gambaran pelaksanaan swamedikasi di wilayah bantul. Rancangan penelitian deskriptif dengan metode penelitian survei secara langsung menggunakan kuesioner dan lembar observasi. Penentuan sampel apotek dan pasien dilakukan menggunakan teknik purposive sampling. Hasil dari penelitian ini menunjukkan bahwa tiga golongan obat yang paling banyak dibeli dalam pelaksanaan swamedikasi adalah analgesik antipiretik (28\%), vitamin/suplemen (19\%), dan obat batuk pilek (15\%). Sebagian besar konsumen telah mengetahui aturan pemakaian obat (71\%), dan Apoteker merupakan faktor pertimbangan dalam pemilihan obat (34\%). Sebanyak 96\% konsumen mengaku membaca label obat pada saat pertama kali pembelian. Pendapat konsumen mengenai konseling yaitu bahwa sebagian besar memerlukan adanya konseling obat tanpa resep (89\%), sebanyak $75 \%$ pernah mendapatkan konseling obat tanpa resep dengan durasi konseling 1-5 menit. Kesimpulan dari penelitian ini adalah Gambaran pelaksanaan swamedikasi obat tanpa resep di Wilayah Bantul menunjukkan bahwa golongan obat tanpa resep yang paling banyak dibeli adalah analgesik antipiretik. Pelaksanaan konseling dalam swamedikasi obat tanpa resep di wilayah Bantul menunjukkan bahwa sebagian besar konsumen (89\%) memerlukan adanya konseling obat dari Apoteker, sebanyak 75\% konsumen pernah mendapatkan konseling dalam swamedikasi obat, dan rata-rata lamanya waktu pemberian konseling obat tanpa resep adalah 5 menit
\end{abstract}

Kata kunci : obat tanpa resep, konseling, swamedikasi

Penulis korespondesi:

Susan Fitria Candradewi

Fakultas Farmasi, Universitas Ahmad Dahlan

Jl.Prof.Dr. Soepomo, S.H.,Yogyakarta

Email: susan.candradewi@pharm.uad.ac.id 


\begin{abstract}
The use of non-prescription drugs of self-medication has been done by the community to treat various conditions of ailments. The drugs which are often used in self-medication generally belong to the class of non-prescription drugs. One of the things which influence people's self-medication is the information about drugs which is easy to be accessed. The concept development of pharmacy services means that pharmacists are in charge of patients in quality of service improvement, so that the pharmacists have a duty to give proper information related to the use of non-prescription drugs. This research aims to determine consumers' opinion regarding counseling of non-prescription drugs and the overview of non-prescription drugs implementation in Bantul. This research is a descriptive research with direct survey method by using questionnaires and observation sheets. The sampling is done by using purposive sampling technique. The result of this research shows that there are three classes of the most widely purchased in the implementation of self-medication which are antipyretic analgesics (28\%), supplements/vitamins (19\%), and the last is cough, cold and flu drugs (15\%). Most consumer already know drugs usage rules, and it is showed by the number of $71 \%$, and pharmacists become factor in considering drug selection is showed by the number of $34 \%$, while $96 \%$ consumers claim to read drug's label at first purchase. Consumers' opinion in counseling is that they most require counseling of non-prescription drugs, which is showed by the number of $89 \%$, while $75 \%$ of consumers had been getting counseling of non-prescription drugs with duration of 1 to 5 minutes. The conclusion of this research is the overview of self-medication implementation of non-prescription drugs in Bantul shows that the most purchased of non-prescription drugs is analgesic antipyretic. Implementation of counseling non prescription drugs in Bantul shows that most (89\%) of the consumers need counseling from pharmacist, as many as $75 \%$ consumers get non prescription drug counseling from pharmacist, and the average time of non prescription drug counseling was 5 minute.
\end{abstract}

Keywords: non-prescription drugs, counseling, self-medication

\title{
PENDAHULUAN
}

Penggunaan obat tanpa resep dalam upaya swamedikasi telah dilakukan secara luas oleh masyarakat. Saat ini ketersediaan obat tanpa resep mencapai kira-kira 100.000 jenis yang digunakan untuk mengobati berbagai kondisi penyakit ringan. Beberapa kondisi tersebut antara lain seperti sakit kepala, demam, flu, konstipasi, rhinitis, jerawat, dismenorhea, diare, batuk pilek, alergi dan beberapa lainnya yang kira-kira terjadi pada jutaan masyarakat tiap tahunnya (Abay dan Amelo, 2010). Swamedikasi muncul didasari pemikiran pada masyarakat bahwa pengobatan sendiri dapat menyembuhkan penyakit ringan tanpa melibatkan tenaga kesehatan (Kartajaya, 2011). Alasan lainnya adalah karena keterbatasan biaya untuk berobat ke dokter, ketiadaan waktu untuk ke dokter, dan akses ke pelayanan kesehatan yang minim (Atmoko dan Kurniawati, 2009). Berdasarkan Riset Kesehatan Dasar yang dilakukan oleh Badan Peneliti dan Pengembangan Kementrian Kesehatan RI pada tahun 2013 menunjukkan bahwa sebanyak 35,2\% rumah tangga di Indonesia menyimpan obat untuk swamedikasi (Anonim, 2013).

Swamedikasi merupakan upaya yang dilakukan penderita dengan tujuan untuk pengobatan penyakit ringan, pengobatan penyakit kronis setelah adanya perawatan dari dokter, dan juga dalam upaya peningkatkan kesehatan (Kartajaya, 2011). Pelaksanaan swamedikasi hendaknya sesuai dengan kriteria penggunaan obat yang rasional, yaitu tepat obat, tepat pasien, tepat dosis, waspada efek samping obat, tidak ada interaksi obat yang bermakna secara klinis, tidak ada duplikasi obat (Hermawati, 2012). Penggunaan obat yang digunakan dalam swamedikasi terbatas pada obat bebas, bebas terbatas dan obat wajib apotek (OWA). Penggunaan obat bebas, bebas terbatas dan obat wajib apotek (OWA) secara benar dapat membantu masyarakat dalam hal swamedikasi. Namun seringkali penggunaan obat untuk swamedikasi tidak sesuai dengan kriteria penggunaan obat yang rasional, sehingga akan menyebabkan terjadinya keamanan yang kurang atau pengeluaran biaya yang tinggi (Kristina et al., 2012). Penelitian yang dilakukan sebelumnya oleh Supardi menunjukkan bahwa 
pengetahuan masyarakat tentang swamedikasi masih rendah (Supardi dan Notosiswoyo, 2006). Disamping itu, kesadaran masyarakat untuk membaca label kemasan obat pada saat membeli juga masih rendah (Supardi dan Notosiswoyo, 2012). Sumber informasi pasien dalam swamedikasi seringkali berasal dari iklan di televisi, dimana seringkali iklan tersebut kurang benar. Pengetahuan konsumen dalam perilaku swamedikasi di Kabupaten Sleman menunjukkan sebesar 52,9\% termasuk dalam kategori rendah meskipun pada penelitian tersebut sebagian besar konsumen telah memenuhi kriteria penggunaan obat yang rasional (Kristina et al., 2012). Keterbatasan pengetahuan konsumen tersebut merupakan salah satu faktor yang menyebabkan terjadinya ketidakrasionalan penggunaan obat apabila pemberian informasi tidak dilakukan secara benar oleh Apoteker (Hermawati, 2012).

Dalam pelayanan kefarmasian Apoteker hendaknya secara langsung bertanggung jawab pada pasien dalam peningkatkan mutu pelayanan yang berarti bahwa Apoteker memiliki kewajiban dan tanggung jawab secara langsung dalam pemberian berbagai macam informasi tentang obat yang digunakan oleh pasien (Anonim, 2004). Berdasarkan latar belakang tersebut maka perlu dilakukan penelitian mengenai gambaran pelaksanaan swamedikasi dan pendapat konsumen terhadap konseling oleh Apoteker. Penelitian ini secara umum bertujuan untuk mengetahui gambaran perilaku swamedikasi oleh masyarakat dan pendapat konsumen mengenai konseling obat tanpa resep oleh Apoteker.

\section{METODE PENELITIAN}

Penelitian ini merupakan penelitian deskriptif non-eksperimental dengan menggunakan metode survei secara langsung kepada responden konsumen apotek di wilayah kota Bantul menggunakan alat penelitian kuesioner. Kuesioner dibagikan secara langsung (Villako et al., 2012) kepada responden konsumen apotek terpilih. Teknik pengambilan sampel apotek dan konsumen menggunakan metode purposive sampling.

Penentuan jumlah apotek sampel menggunakan persamaan yang dikemukakan oleh Nazir (1998) sebagai berikut:

$$
n=\frac{N \cdot p(1-p)}{(N-1) D+p(1-p)}
$$

Keterangan:

$\mathrm{n}=$ besar sampel minimal

$\mathrm{N}=$ besar populasi $=85$

$\mathrm{p}=$ proporsi populasi sebesar $50 \%=0.5$

$\mathrm{D}=$ estimasi terhadap mean yang besarnya $\mathrm{B}^{2} / 4$ dimana $\mathrm{B}$ adalah bound of error yaitu 0.25

$1-\mathrm{p}=$ proporsi sisa di dalam populasi $=0,5$

Berdasarkan rumus tersebut, maka dapat dihitung jumlah sampel minimal yang harus diambil yaitu sebagai berikut:

$$
\begin{aligned}
& n=\frac{85 \times 0,5(1-0,5)}{(85-1) \times 0,1+(1-0,5)} \\
& n=2,38 \approx 3
\end{aligned}
$$

Jadi sampel minimal apotek dalam penelitian ini adalah 3 apotek.

Sampel minimal responden konsumen apotek dihitung menggunakan rumus sebagai berikut:

$$
n \geq p . q\left(\frac{Z_{1 / 2 \alpha}}{b}\right)^{2}
$$

Keterangan:

$\mathrm{n} \quad=$ jumlah sampel minimal

$\mathrm{p}=$ proporsi populasi persentase kelompok pertama $=0,5$

$\mathrm{q}=$ proporsi sisan dalam populasi $(100-\mathrm{p})=0,5$ 
$\mathrm{Z}_{1 / 2 \alpha}=$ derajad koefisisen konfidensi pada taraf kepercayaan $95 \%(1,96)$

$\mathrm{b}=$ presentase perkiraan kemungkinan membuat kekeliruan dalam menentukan ukuran sampel (berkisar 0,1 sampai 0,5$) \rightarrow 0,1$

(Nawawi, 2007). Sehingga perhitungan sampel minimal yang harus diteliti berdasarkan rumus diatas adalah:

$n \geq 0,5 \times 0,5\left(\frac{1,96}{0,1}\right)^{2}$

$n \geq 96,04$

Jadi berdasarkan rumus tersebut sampel minimal responden apotek adalah 97 pasien.

\section{Alat dan Bahan}

Alat yang digunakan dalam penelitian ini yaitu kuesioner yang diberikan kepada konsumen apotek dan memuat 20 pertanyaan, yaitu:

a. Data demografi responden konsumen apotek yang memuat lima pertanyaan yang terdiri dari umur, jenis kelamin, pekerjaan, pendidikan, dan jarak tempat tinggal dengan apotek.

b. Pertanyaan faktual responden apotek yang terdiri dari golongan obat yang dibeli responden, aturan pakai obat, pertimbangan pemilihan obat, dan pembacaan label kemasan saat pertama kali pemakaian.

c. Pendapat responden mengenai perlu tidaknya mendapat konseling dari apoteker, perlu tidaknya mendapat konseling obat tanpa resep dari apoteker.

d. Pelaksanaan dan pelayanan konseling obat yang meliputi pernah tidaknya mendapat konseling,dan lamanya pemberian konseling.

\section{Jalannya Penelitian}

Penelitian ini dimulai dari persiapan proposal, perijinan dan kuesioner. Proposal yang telah disetujui selanjutnya memulai melakukan pengurusan ijin penelitian di Dinas Kesehatan Kabupaten Bantul, dan BAPPEDA Kabupaten Bantul. Setelah ijin diperoleh, dilakukan sampling apotek yang dilakukan pada 4 Apotek yang tersebar di Kota Bantul bagian utara, selatan, barat dan timur. Pengambilan sampel konsumen apotek dilakukan kepada semua konsumen yang datang ke Apotek dan memenuhi kriteria inklusi penelitian. Selanjutnya konsumen akan mengisi kuesioner yang berisi data demografi konsumen, pelaksanaan konseling obat tanpa resep dan pendapat konsumen tentang swamedikasi obat tanpa resep. Data yang diperoleh selanjutnay dianalisis dengan menggunakan SPSS. tahapan terakhir adalah laporan hasil penelitian yang telah dilaksanakan.

\section{Definisi Operasional}

Definisi operasional dalam penelitian ini adalah sebagai berikut:

1. Apotek dalam penelitian ini adalah tempat dilakukannya penelitian yang dipimpim oleh seorang apoteker pengelola apotek yang telah diberi izin mengelola apotek dan memberikan izin penelitian.

2. Konsumen dalam penelitian ini merupakan konsumen yang membeli obat tanpa resep dan mendapat konseling dari apoteker.

3. Obat tanpa resep dalam penelitian ini merupakan obat-obat yang dapat dibeli tanpa menggunakan resep yang terdiri dari Over-The-Counter (OTC) yaitu obat bebas dan obat bebas terbatas, dan obat wajib apotek (OWA).

4. Swamedikasi dalam penelitian ini adalah perilaku konsumen dalam hal pengobatan sendiri untuk mengatasi penyakit-penyakit ringan tanpa ada keterlibatan tenaga kesehatan (dokter).

\section{Analisis Data}

Analisis data dilakukan berdasarkan hasil penelitian yang berasal dari kuesioner yang diisi oleh responden konsumen apotek yang berupa jawaban kuesioner yang meliputi demografi responden dan 
pertanyaan faktual yang berkenaan dengan pelaksanaan konseling obat tanpa resep. Analisis data dilakukan secara statistik frekuensi dan persentase mengenai data demografi responden dan pertanyaan faktual responden Apotek, pendapat responden Apotek mengenai konseling obat tanpa resep, dan pelaksanaan konseling obat tanpa resep.

\section{Keterbatasan Penelitian}

Dalam penelitian yang dilakukan, ada beberapa keterbatasan penelitian dalam hal metode penelitian dalam hal pengambilan sampel yang dilakukan secara non random. Sehingga hasil penelitian tidak menggambarkan secara keseluruhan. Kesulitan pengambilan sampel apotek secara random dikarenakan belum tentu apotek bersedia memberikan izin penelitian.

Kelemahan yang dihadapi di lapangan antara lain sulitnya mencari responden yang bersedia mengisi kuesioner. Sebagian besar konsumen tidak memiliki banyak waktu untuk bersedia mengisi kuesioner karena bisaanya mereka membeli obat disela-sela pulang dari kantor, sekolah, maupun dari tempat lainnya sehingga mereka menolak untuk mengisi kuesioner yang diberikan. Selain itu penyebaran apotek sampel yang berdekatan karena kesulitan dalam mencari apotek yang bersedia untuk memberikan izin.

\section{HASIL DAN PEMBAHASAN}

\section{Karakteristik demografi responden}

Responden yang terlibat dalam penelitian ini adalah 100 responden. Karakteristik responden dalam penelitian ini meliputi jenis kelamin, usia, pekerjaan, pendidikan dan jarak tempat tinggal dengan apotek. Karakteristik dasar ini diperlukan untuk mengetahui latar belakang konsumen, karena perbedaan latar belakang sosial, budaya dan pendidikan akan mempengaruhi hasil penelitian.

Tabel I. Karakteristik demografi responden

\begin{tabular}{|c|c|c|c|}
\hline Karakteristik & & $\begin{array}{c}\text { Jumlah } \\
\text { (responden) }\end{array}$ & $\begin{array}{c}\text { Persentase } \\
(\%)\end{array}$ \\
\hline \multirow{2}{*}{ Jenis Kelamin } & Laki-laki & 55 & 55 \\
\hline & Perempuan & 45 & 45 \\
\hline \multirow[t]{6}{*}{ Usia } & $<20$ tahun & 5 & 5 \\
\hline & $21-30$ & 33 & 33 \\
\hline & tahun & 28 & 28 \\
\hline & $31-40$ & 24 & 24 \\
\hline & tahun & 7 & 7 \\
\hline & $\begin{array}{l}\text { 41-50 Ahun } \\
>50 \text { tahun }\end{array}$ & & \\
\hline \multirow[t]{7}{*}{ Pekerjaan } & Pelajar & 17 & 17 \\
\hline & Wiraswasta & 25 & 25 \\
\hline & Karyawan & 8 & 8 \\
\hline & PNS & 31 & 31 \\
\hline & Ibu Rumah & 17 & 17 \\
\hline & Tangga & 2 & 2 \\
\hline & Pensiunan & & \\
\hline \multirow[t]{4}{*}{ Pendidikan } & SD dan & 8 & 8 \\
\hline & SLTP & 62 & 62 \\
\hline & SLTA & 30 & 30 \\
\hline & $\begin{array}{l}\text { Perguruan } \\
\text { Tinggi }\end{array}$ & & \\
\hline Jarak Tempat & $\leq 5 \mathrm{~km}$ & 87 & 87 \\
\hline tinggal dengan & $6-9 \mathrm{Km}$ & 7 & 7 \\
\hline Apotek & $>9 \mathrm{~km}$ & 6 & 6 \\
\hline
\end{tabular}

Jenis kelamin laki-laki merupakan yang paling banyak melakukan swamedikasi dibandingkan wanita. Usia dapat menjadi salah satu faktor yang berpengaruh dalam tingkat pengetahuan, selain itu usia juga akan berpengaruh terhadap cara pandang, pemikiran, dan penilaian konsumen terhadap materi kuesioner yang dihubungkan dengan pengalaman yang pernah dialami. Usia konsumen yang 
menjadi responden dalam penelitian ini berturut-turut tiga besar adalah 20-30 tahun sebesar 33\%, 3140 tahun 28\%, 41-50 tahun 24\% Berdasarkan penelitian sebelumnya yang dilakukan oleh Baran (2008), disebutkan bahwa populasi muda lebih sering menggunakan obat tanpa resep. Usia 20-30 tahun merupakan usia yang paling banayak dalam melakukan swamedikasi (Alaqeel and Abanmy, 2015). Pekerjaan konsumen yang melakukan swamedikasi dalam penelitian ini sebagian besar adalah PNS $31 \%$ diikuti oleh wiraswasta $25 \%$.

Sebanyak 62\% konsumen merupakan lulusan Sekolah Menengah Atas (SMA), hal ini sesuai dengan penelitian yang dilakukan oleh Villako et al., (2012) bahwa sebagian besar responden yang melakukan pembelian obat tanpa resep merupakan lulusan SMA (42\%).Tingkat pendidikan akan mempengaruhi tingkat pengetahuan konsumen mengenai penyakit dan informasi mengenai obat-obat yang digunakan dalam swamedikasi. Melalui faktor pendidikan, diharapkan semakin tinggi pula tingkat pengetahuan dan intelektualitas konsumen yang terlibat dalam penelitian. Selain itu pekerjaan akan berpengaruh terhadap penghasilan dari konsumen, semakin besar penghasilannya maka akan semakin besar keinginan konsumen menbeli obat tanpa resep dan suplemen kesehatan (Villako et al., 2012).

Distribusi konsumen berdasarkan jarak tempat tinggal dengan apotek dinilai perlu dilakukan karena akan mempengaruhi frekuensi kunjungan konsumen ke apotek. Berdasarkan wawancara dengan konsumen, dapat diketahui bahwa jarak tempat tinggal konsumen dengan apotek akan mempengaruhi frekuensi kunjungan ke apotek dan alasan dalam pemilihan apotek. Terlihat dari hasil penelitian, $48 \%$ konsumen memilih apotek yang dekat dengan rumah. Menurut survei yang dilakukan oleh Adriayanita (2004) alasan pemilihan apotek 82,7\% karena dekat dengan rumah (Adriayanita, 2004)

\section{Pelaksanaan swamedikasi dan pendapat konsumen mengenai konseling obat tanpa resep}

Penelitian ini bertujuan untuk mengetahui kondisi secara umum dari segi pandang konsumen dan untuk mengetahui keinginan konsumen terhadap pelayanan kefarmasian mengenai obat tanpa resep.

Golongan obat tanpa resep (OTR) berdasarkan kelas terapi yang dibeli oleh konsumen dalam melakukan swamedikasi bermacam-macam. Berdasarkan hasil penelitian diketahui bahwa delapan golongan obat dengan persentase terbesar adalah golongan analgesik antipiretik yaitu sebesar $28 \%$, vitamin/suplemen sebanyak 19\%, obat batuk dan pilek sebesar 15\%, obat-obat golongan antihistamin dan antialergi sebanyak 8\%, antibiotik sebesar 6\% dan selanjutnya antifungi, anti anemia, dan obat saluran pencernaan memiliki presentase yang sama yaitu sebesar 3\% dan lain-lain sebesar $15 \%$.

Hal ini senada dengan penelitian sebelumnya tentang Perspektif Sosial Mengenai Obat Tanpa Resep (Wazaify et al., 2005) bahwa sebanyak 76,4\% konsumen membeli analgesik antipiretik sebagai persediaan obat di rumah, dan diikuti dengan vitamin dan atau mineral (43,4\%). Penelitian lainnya yang dilakukan oleh Villako et al., (2012) tentang Faktor Yang Berpengaruh Terhadap Pembelian Dan Konseling Obat Resep Dan Obat Tanpa Resep Di Tallin Estonia menunjukkan bahwa obat tanpa resep yang dibeli konsumen selama 12 bulan paling banyak adalah golongan analgesik (38\%), diikuti obat batuk dan flu (21\%) (Villako et al., 2012).

Pelaksanaan swamedikasi dalam penelitian ini diperoleh dari kuesioner yang diisi oleh konsumen secara langsung meliputi apakah konsumen telah mengetahui aturan pemakaian obat, pertimbangan pemilihan obat, pembacaan label kemasan obat pada saat pertama kali pembelian obat tanpa resep, perlu tidaknya mendapatkan konseling obat tanpa resep dati Apoteker, pernah tidaknya mendapat konseling obat dari Apoteker, lama pemberian konseling obat tanpa resep dari apoteker. Tabel III menunjukkan mengenai pelaksanaan swamedikasi obat tanpa resep di apotek-apotek wilayah kota Bantul. 
Tabel II. Delapan besar golongan obat tanpa resep yang paling banyak dibeli konsumen Apotek di wilayah kota Bantul

\begin{tabular}{lcc}
\hline \multicolumn{1}{c}{ Golongan obat } & Jumlah & Presentase (\%) \\
\hline Analgesik antipiretik & 28 & $28 \%$, \\
Vitamin/suplemen & 19 & $19 \%$, \\
obat batuk dan pilek & 15 & $15 \%$ \\
Antihistamin dan antialergi & 8 & $8 \%$ \\
Antibiotik & 6 & $6 \%$, \\
Antifungi & 3 & $3 \%$ \\
Anti-anemia & 3 & $3 \%$ \\
obat saluran percernaan & 3 & $3 \%$ \\
Lain-lain & 15 & $15 \%$ \\
Total & 100 & $100 \%$ \\
\hline
\end{tabular}

Tabel III.Gambaran swamedikasi obat tanpa resep di apotek wilayah kota Bantul

\begin{tabular}{lcc}
\hline \multicolumn{1}{c}{ Golongan obat } & Jumlah & $\begin{array}{c}\text { Presentase } \\
(\%)\end{array}$ \\
\hline Aturan Pakai Obat & 72 & $72 \%$ \\
$\quad$ Mengetahui & $28 \%$ & $28 \%$ \\
Tidak Mengetahui & & \\
Pertimbangan Pemilihan Obat & 34 & $34 \%$ \\
$\quad$ Apoteker & 23 & $23 \%$ \\
Pengalaman & 15 & $15 \%$ \\
Dokter & 10 & $10 \%$ \\
Iklan Televisi & 9 & $9 \%$ \\
Informasi dari Teman & 9 & $9 \%$ \\
Lain-lain & & \\
Pembacaan Label Kemasan Pada Saat Pertama Kali Pemakaian Obat & 96 & $96 \%$ \\
Membaca & 3 & $3 \%$ \\
Tidak & 1 & $1 \%$ \\
Tidak mengisi & & \\
Konseling Obat dari Apoteker & 89 & $89 \%$ \\
Perlu & 11 & $11 \%$ \\
Tidak & & \\
Pernah Mendapatkan Konseling Obat Tanpa Resep dari Apoteker & 75 & $75 \%$ \\
Pernah & 25 & $25 \%$ \\
Tidak pernah & & $75 \%$ \\
Lamanya Pemberian Konseling Obat Tanpa Resep Dari Apoteker & 75 & $75 \%$ \\
1-5 menit & & $71 \%$ \\
5-10 menit & & 715 menit \\
$>15$ menit & 7 & \\
\hline
\end{tabular}

\section{Aturan pakai obat}

Responden Apotek sebagian besar telah mengetahui aturan pakai obat (72\%), dan $28 \%$ tidak mengetahui aturan pakai obat. Konsumen yang mengetahui aturan pakai obat kemungkinan telah beberapa kali membeli obat yang sama untuk indikasi yang sama ataupun telah beberapa kali membaca label kemasan obat yang sama, sedangkan konsumen yang tidak mengetahui aturan pakai kemungkinan baru pertama kali membeli obat untuk indikasi tertentu sehingga belum mengetahui 
aturan pakai obat tersebut. Konsumen dalam melakukan swamedikasi sebagian besar informasi mengenai penggunaan obat diperoleh dari iklan di televisi (Widayati, 2013).

Apoteker bertanggung jawab terhadap pemberian informasi mengenai pemakaian obat yang dibeli konsumen. Selain sebagai bentuk pelayanan kefarmasian yang berorientasi terhadap konsumen (pharmaceutical care) juga dapat digunakan sebagai salah satu media promosi terhadap pelayanan yang diberikan oleh Apotek.

\section{Pertimbangan pemilihan obat}

Faktor yang berpengaruh terhadap pertimbangan pasien dalam pemilihan obat diantaranya berdasarkan saran dari apoteker, informasi dari teman, pengalaman, informasi dari dokter dan iklan TV.

Hasil penelitian ini menunjukkan bahwa konsumen yang memilih membeli obat tanpa resep karena pertimbangan dari apoteker sebanyak $34 \%$, sebanyak $23 \%$ konsumen membeli obat tanpa resep berdasarkan pengalaman sebelumnya, sebanyak $15 \%$ konsumen memilih karena pertimbangan dari dokter, sebanyak $10 \%$ memilih membeli obat tanpa resep karena iklan dari TV, konsumen memilih obat tanpa resep karena informasi dari teman sebanyak 9\%, dan 9\% karena alasan lain-lain.

Apoteker telah berperan dalam membantu pemilihan obat tanpa resep berdasarkan gejala-gejala dan keluhan yang dipaparkan konsumen, ditunjukkan bahwa sebanyak 34\% konsumen mengikuti saran Apoteker. Peran Apoteker dalam konseling obat tanpa resep antara lain sebagai sumber informasi yang utama bagi konsumen termasuk dalam memberikan pertimbangan dalam memilih obat.

Hasil penelitian ini senada dengan penelitian sebelumnya yang dilakukan Yousef et al., (2008), diketahui bahwa faktor yang mempengaruhi pemilihan obat tanpa resep antara lain saran/rekomendasi dari apoteker $14,2 \%$, informasi dari teman $17,6 \%$, informasi dari tenaga kesehatan lainnya (dokter, dokter gigi atau perawat) sebesar $21,9 \%$, dan berdasarkan pengalaman sebanyak 60,5\%.

Penelitian lain yang senada mengenai Penggunaan Obat Tanpa Resep dalam Pencegahan dan Pengobatan Infeksi Saluran Pernafasan Atas disebutkan bahwa sebanyak 30\% konsumen membeli obat tanpa resep berdasarkan saran/rekomendasi apoteker, dan sebanyak $20 \%$ berdasarkan pengalaman dan informasi dari dokter (Baran et al., 2008). Sedangkan dalam penelitian lain yang dilakukan di Esthonia menunjukkan bahwa masyarakat yang melakukan swamedikasi mempercayai rekomendasi Apoteker dalam pemilihan obat swamedikasi (Villako et al., 2012). Apoteker yang bekerja pada komunitas di Parana brazil mengatakan bahwa Apoteker memberikan rekomendasi pemilihan obat dalam swamedikasi sebanyak 300 rekomendasi setiap bulannya (Halila et al., 2015).

Pasien (konsumen) merasa terbantu dengan adanya partisipasi dari Apoteker dalam membantu memilihkan obat yang tepat bagi mereka. Oleh karena itu Apoteker sebaiknya tidak perlu menunggu konsumen meminta namun lebih proaktif dalam memberikan pelayanan kepada pasien dalam pemilihan obat tanpa resep. Sehingga pelaksanaan kefarmasian terhadap pelayanan obat tanpa resep perlu dilaksanakan lebih jauh lagi.

\section{Pembacaan label kemasan pada saat pertama kali pemakaian}

Berdasarkan dari hasil penelitian dapat diketahui sekitar 96\% konsumen membaca label kemasan pada saat pertama kali membeli, sedangkan $3 \%$ tidak membacanya, dan $1 \%$ tidak mengisi kuesioner.

Konsumen memiliki keinginan mendapatkan informasi sebanyak-banyaknya mengenai obat tanpa resep yang dibelinya hal ini terlihat pada hasil wawancara dengan konsumen diketahui bahwa konsumen yang tidak membaca label kemasan pada saaat pertama kali pemakaian mengaku telah mendapat informasi yang lengkap dari Apoteker sehingga merasa tidak perlu lagi membaca label kemasan. Alasan lainnya konsumen merasa bahwa obat-obat yang dapat dibeli tanpa resep relatif aman dan jarang sekali memiliki efek samping yang serius. 
Pendapat konsumen mengenai perlu tidaknya mendapat konseling obat dari apoteker

Konsumen apotek sebagian besar memerlukan konseling dari Apoteker mengenai obat-obat yang dibelinya baik obat resep maupun obat tanpa resep (89\%), 11\% konsumen mengatakan tidak memerlukan konseling dari apoteker. Penelitian sebelumnya yang dilakukan (Villako et al., 2012) menunjukkan hasil yang sama bahwa harapan konsumen paling besar dalam pembelian obat tanpa resep adalah mendapatkan konseling secara profesional oleh Apoteker, dan mendapatkan rekomendasi dalam pemilihan obat. Izzatin (2015) mengatakan bahwa sebagian konsumen yang pernah mendapatkan konseling dalam swamedikasi merasa puas terhadap konseling yang diberikan oleh Apoteker, sebanyak 75\% mengatakan membutuhkan Apoteker dalam swamedikasi, dan sebanyak 91\% konsumen sangat setuju bahwa Apoteker memiliki peranan penting dalam pelayanan swamedikasi (Izzatin, 2015).

\section{Pernah tidaknya mendapat konseling obat tanpa resep}

Konsumen yang pernah mendapatkan konseling obat tanpa resep memiliki persentase yang lebih besar daripada konsumen yang belum pernah mendapatkan konseling obat tanpa resep $(75 \% ; 25 \%)$. Berdasarkan data tersebut dapat disimpulkan bahwa apoteker telah berpartisipasi dan memiliki kesadaran yang tinggi untuk dapat memberikan segala macam informasi dan konseling kepada konsumen terutama terhadap obat tanpa resep.

Mengacu pada survei OTC oleh U.S. Pharmacist, sebanyak 58,1\% apoteker dalam poling menyatakan bahwa apoteker sangat sering mendapatkan pertanyaan yang berhubungan dengan produk OTC dan sebagian besar $(94,7 \%)$ mengatakan bahwa apoteker memiliki peran dalam konseling konsumen mengenai pengobatan dengan obat OTC. Bagi pasien, ini berarti terjadi kontrol yang lebih baik pada kemampuan pengobatan sendiri. Konseling Apoteker dalam swamedikasi merupakan salah satu standar pelayanan kefarmasian di Apotek yang diatur oleh Undang-Undang, sehingga setiap Apoteker hendaknya memberikan pemberian informasi atau konseling kepada konsumen. Dalam penelitian yang dilakukan oleh Bardage (2013) yang membandingkan mengenai konseling dan rekomendasi yang diberikan oleh Apoteker dengan sales promotion girls (SPG) produk tertentu menunjukkan bahwa sebagian besar Apoteker memberikan konseling dan rekomendasi pada pasien demam dan flu sebesar 44\% (Bardage et al., 2013).

\section{Lamanya pemberian konsultasi obat tanpa resep}

Berdasarkan dari hasil penelitian ini diperoleh bahwa durasi/lamanya pemberian konseling obat tanpa resep terhadap konsumen berbeda-beda. Sebagian besar mendapat konseling dalam waktu 1 menit sampai dengan 5 menit yaitu sebanyak 75\%, sebanyak $11 \%$ mendapat konseling selama 5 menit sampai dengan 10 menit, dan konsumen yang mendapat konseling selama 10 menit sampai dengan 15 menit dan selama lebih dari 15 menit memiliki jumlah yang sama yaitu $7 \%$.

Dalam penelitian sebelumnya yang dilakukan oleh Dwi Astuti (2003) mengenai Pelaksanaan Informasi obat, dapat diketahui sebanyak $37 \%$ tenaga farmasi memberikan informasi obat selama lebih dari 120 detik, 25\% tenaga farmasi memberikan informasi selama 30-60 detik, 13\% memberikan informasi selama kurang dari 30 detik, dan 6\% memberikan informasi selama 90-120 detik.

Lamanya pemberian konseling obat tanpa resep untuk masing-masing Apoteker maupun konsumen berbeda-beda. Hal ini seringkali disebabkan karena konsumen tidak memiliki banyak waktu (terburu-buru), konsumen enggan berkonseling dengan apoteker, maupun sikap konsumen yang kurang kooperatif. Sehingga lamanya pemberian konseling sebaiknya disesuaikan dengan kondisi pada saat itu dan merupakan pilihan apoteker untuk memberikan konseling obat kepada pasien dengan memanfaatkan waktu yang terbatas sekalipun.

\section{KESIMPULAN}

Gambaran pelaksanaan swamedikasi obat tanpa resep di Wilayah Bantul menunjukkan bahwa golongan obat tanpa resep yang paling banyak dibeli adalah analgesik antipiretik. Pelaksanaan konseling dalam swamedikasi obat tanpa resep di wilayah Bantul menunjukkan bahwa sebagian besar konsumen (89\%) memerlukan adanya konseling obat dari Apoteker, sebanyak 75\% konsumen pernah 
mendapatkan konseling dalam swamedikasi obat, dan rata-rata lamanya waktu pemberian konseling obat tanpa resep adalah 5 menit.

\section{DAFTAR PUSTAKA}

Abay, S.M., Amelo, W., 2010. Assessment of Self-medication practices among medical, pharmacy, health science students in Gondar University, Ethiopia. J. Young Pharm, 2: 306-310.

Adriayanita, R., 2004. Pelaksanaan Informasi obat dengan Resep di Apotek Wilayah Kecamatan Semarang Barat Kota Semarang Provinsi Jawa Tengah, Yogyakarta (Skripsi, Fakultas Farmasi Universitas Gadjah Mada,). Skripsi, Fakultas Farmasi Universitas Gadjah Mada, yogyakarta.

Alaqeel, S. dan Abanmy, N.O., 2015, Counselling practices in community pharmacies in Riyadh, Saudi Arabia: a cross-sectional study. BMC Health Services Research, 15:557-565

Anonim, 2013. Riset Kesehatan Dasar 2013.

Anonim, 2004, Keputusan Menteri Kesehatan Republik Indonesia Nomor 1027/MENKES/SK/IX/2004 tentang Standar Pelayanan Kefarmasian di Apotek, Depkes RI, Jakarta.

Atmoko, W. dan Kurniawati, I., 2009, Swamedikasi: Sebuah Respon Realistik Perilaku Konsumen Di Masa Kritis. Bisnis dan Kewirausahaan, 2 (3): 233-247.

Baran, S., Teul, I., Ignys-O'byrne, A., 2008, Use of Over The Counter Medications in Prevention of Upper Respiratory Tract Infections, journal of Physiology and Pharmacology, suppl 6: 135-143.

Bardage, C., Westerlund, T., Barzi, S., dan Bernsten, C., 2013, Non-prescription medicines for pain and fever--a comparison of recommendations and counseling from staff in pharmacy and general sales stores. Health Policy (Amsterdam, Netherlands), 110: 76-83.

Dwi Astuti, C, 2003, Pelaksanaan Pelayanan Informasi Obat di Sepuluh Apotek Besar di Kabupaten Bantul, Skripsi, Fakultas Farmasi UGM, Yogyakarta.

Halila, G.C., Junior, E.H., Otuki, M.F., dan Correr, C.J., 2015, The practice of OTC counseling by community pharmacists in Parana, Brazil. Pharmacy Practice, 13(4):597-604

Hermawati, D., 2012, Pengaruh Edukasi Terhadap Tingkat Pengetahuan dan Rasionalitas Penggunaan Obat Swamedikasi pengunjung di dua Apotek kecamatan Cimanggis Depok. Skripsi, Fakultas MIPA Universitas Indonesia.

Izzatin, I., 2015, Persepsi Pasien Terhadap Pelayanan Swamedikasi Oleh Apoteker Di Beberapa Apotik Wilayah Surabaya Selatan. Jurnal Ilmiah Mahasiswa Universitas Surabaya, 4(2):53-67

Kartajaya, H., 2011. Self-Medication, Who Benefits and Who is at Loss (p.3). Indonesia: MarkPlus Insight.

Kristina, S.A., Prabandari, Y.S., dan Sudjaswadi, R., 2012, Perilaku pengobatan sendiri yang rasional pada masyarakat. Berita Kedokteran Masyarakat (BKM), 23: 176-183

Nawawi, H., 2007, Metode Penelitian Sosial, 157-160, Gadjah Mada University Press, Yogyakarta.

Rantucci, Melanie J., 1997, Pharmacist Talking with Patients: a Guide to Patients Counseling, 82-84, Baltimore, Pennsylvania

Supardi, S. dan Notosiswoyo, M., 2006, Pengaruh penyuluhan obat menggunakan leaflet terhadap perilaku pengobatan sendiri di tiga kelurahan Kota Bogor. Buletin Penelitian Sistem Kesehatan, 9

Supardi, S. dan Notosiswoyo, M., 2012, Pengobatan sendiri sakit kepala, demam, batuk dan pilek pada masyarakat di Desa Ciwalen, Kecamatan Warungkondang, Kabupaten Cianjur, Jawa Barat. Pharmaceutical Sciences and Research (PSR), 2(3):134-144

Suryawati, S., 1997, Etika Promosi obat Bebas dan Bebas Terbatas. Disampaikan dalam Simposium Nasional obat Bebas dan Bebas Terbatas 23 Juni 1997.

Villako, P., Volmer, D., dan Raal, A., 2012. Factors influencing purchase of and counselling about prescription and OTC medicines at community pharmacies in Tallinn, Estonia. Acta Pol Pharm, 9: 335-340.

Wazaify, M., Shields, E., Hughes C.M., McElnay J.C., 2005, Societal perspective on over-the-counter meddicine, Family Practice 22 :171-173. 
Widayati, A., 2013. Swamedikasi di kalangan masyarakat perkotaan di kota Yogyakarta. Jurnal Farmasi Klinik Indonesia, 145-152

Yousef AM., dkk, 2008, Self Medication Patterns in Amman, Jordan, Pharm World Sci 30: 24-30. 
